LSE ‘Europe in Question’ Discussion Paper Series

\title{
EU Diplomacy at 27: United in Diversity?
}

Nickolas Cherrier

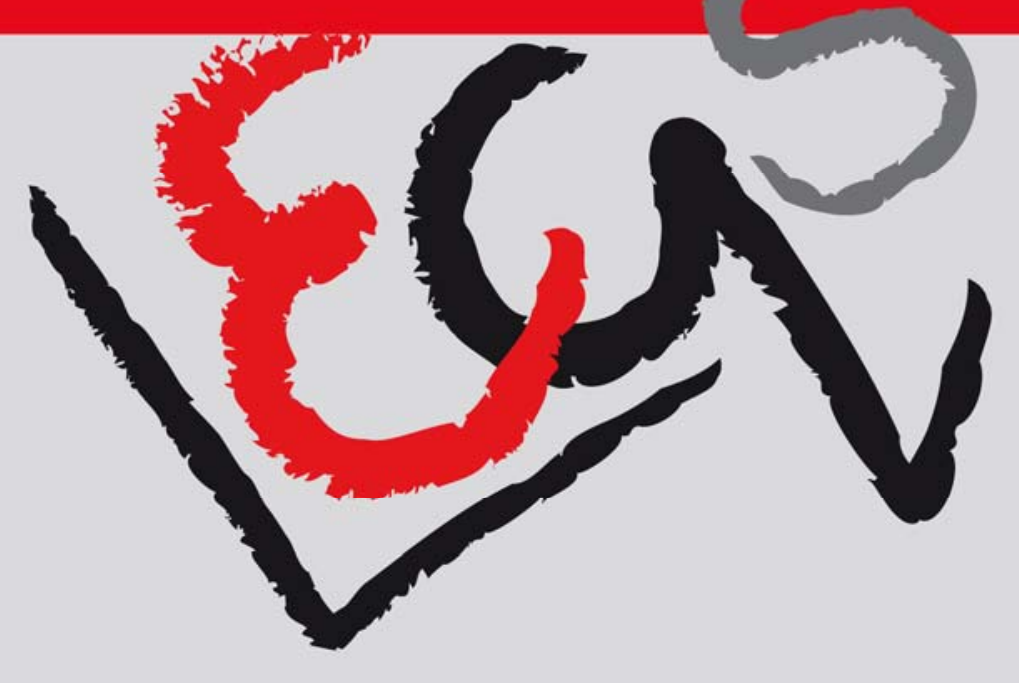




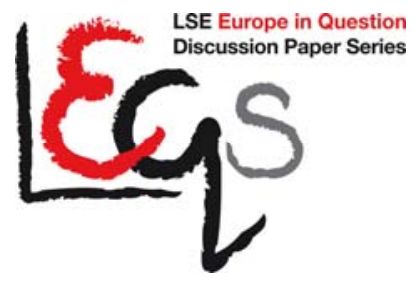

\section{Editorial Board}

Dr. Joan Costa-i-Font

Dr. Vassilis Monastiriotis

Dr. Jonathan White

Ms. Katjana Gattermann

All views expressed in this paper are those of the author and do not necessarily represent the views of the editors or the LSE.

(C) Nickolas Cherrier 


\title{
EU Diplomacy at 27: United in
}

\section{Diversity?}

\author{
Nickolas Cherrier*
}

\begin{abstract}
This paper explores the role played by the newly created European External Action Service as an instrument of cooperation for EU foreign policy. Using two-dimensions spatial modelling to represent decision making at 27 in a unanimity rule Foreign Affairs Council, it highlights the role of agenda-setting, while acknowledging the importance of saliency and coalition sizes. It confirms the notion that it is in the interest of less influential Member States to free ride, while it remains in the interest of more influential Member States to impose their preferences on others. In exploring third party diplomacy and the wider EU institutional setting, it concludes that the EEAS carries efficiency gains and results in a redistribution of utility across Member States. Overall, the EEAS is not seen as a supranational foreign policy maker, but rather as an instrument reinforcing the influence of Member States.
\end{abstract}

* Simon Kucher \& Partners 233 High Holborn, London WC1V 7DN, UK Email: nickolas.cherrier@simon-kucher.com 


\section{Table of Contents}

Abstract

1. Introduction 1

1.1. United we rise, divided we fall 2

1.2. EEAS infancy 4

1.3. Applying game theory 6

2. Decision making and the importance of agenda setting in the $\begin{array}{lr}\text { Foreign Affairs Council } & 8\end{array}$

2.1. Methodology 9

2.2. Coalitions when 27 players matter 11

$\begin{array}{ll}\text { 2.3. The powers of the agenda setter } & 13\end{array}$

2.4. The Empowerment of the agenda setter 15

3. EEAS: An Intergovernmental European Ministry of Foreign $\begin{array}{ll}\text { Affairs } & 22\end{array}$

3.1. Efficient coordination $\quad 22$

3.2. Utility redistribution 25

3.3. The CFSP Hydra 27

$\begin{array}{lr}\text { 4. Conclusions } & 29\end{array}$

$\begin{array}{ll}\text { References } & 31\end{array}$ 


\section{EU Diplomacy at 27: United in}

\section{Diversity?}

\section{Introduction}

The motto 'united in diversity' is a perfect representation of a game where cooperation is possible despite diverging preferences. This paper addresses the following question: How does the European External Action Service (EEAS) change the game of foreign policy formation and coordination within the European Union institutional framework? This paper will draw on graphical representation of game theoretical diagrams and strategic thinking to summarize the core essence of the question at stake.

The office of the High Representative of the Union for Foreign Affairs and Security Policy (HR/VP) and the EEAS are in fact two sides of the same puzzle. I argue that the EEAS has the mantle of an efficient inter-State coordination instrument which empowers the office of the High Representative through information gathering and agenda setting. Furthermore, the institutional changes are justified not solely on grounds of efficiency but also on grounds of redistribution, as the unanimity framework allows for side payments to benefit free riders. Overall the EEAS must not be mistaken for a merger of foreign policies, as the game remains intergovernmental.

The paper is divided into three distinct sections. First, I will summarize the literature relevant to the question. Secondly, I will explain the methodology of two-dimensions spatial modelling and its relevance to represent the 
unanimity voting procedure in the Foreign Affairs Council. Through this model, I will draw attention to the agenda setting function under Pareto optimal conditions. I will argue that a service such as the EEAS has information gathering capacity which enables the High Representative to be an effective supranational entrepreneur. Furthermore, strategic thinking represented in a two-by-two matrix and decision tree emphasize a mechanism whereby some Member States have an interest in minimizing transaction costs and following the lead of the agenda setter, while others must push their own agenda forward. In the third and last section, I will consider budgetary and organizational structures to underline that the reorganization of the EU institutional framework seems to make the EEAS an efficient coordination instrument. Consensus dynamics under this framework also allow for a redistribution of resources. Finally, we will acknowledge a logic of foreign policy coordination, and not one of foreign policy unification.

\subsection{United we rise, divided we fall}

Conventional wisdom points towards a decline of European influence in world affairs. The rise of the United States and the USSR along with the dismantlement of European colonial powerhouses marked the end of European dominance many would argue. This view is particularly prominent in the realist and neo-realist theories of international relations. The underlying principle for the decline of Europe is based on a politico-militarist assumption of a zero-sum game. Of course, much has changed since the Cold war and the fall of the Soviet Union. Several realists predicted a split of the transatlantic alliance (Mearsheimer, 1990; Walt, 1998; Waltz, 2000; Kupchan, 2002), while others simply diminished the role of Europe (Huntington, 1993; Grant, 2009). 
What has seemed clear in the 'new world order' is that countries such as India and China are on the rise (Leonard, 2005).

Known for his rejection of Haas's (1958) integrationist spillover theory, Andrew Moravcsik (1997, 2008) uses what he coined a liberal intergovernmentalist approach to European integration. In his paradigm, States remain primarily motivated by interests; however these are subject to social norms, economic interdependence and institutions. Not unlike constructivism, this allows for a more positive view of world affairs where competition among States does not necessarily result in a zero-sum game (Moravcsik, 2009).

The EU as a whole has, according to several authors (Forster \& Wallace, 1996; Hill, 1996; Smith, 1998), showed its inability to act decisively. In Maastricht, the then twelve member States agreed to transform the European Political Cooperation (EPC), in essence a 'informal, "club-like" atmosphere' (Smith, 1998: 4), into a Common Foreign and Security Policy (CFSP). In doing so, it was expected that European Member States would coordinate more efficiently their foreign policy, even perhaps rising to superpower status. In contrast, Hill (1993) predicted accurately the emergence of a 'capabilitiesexpectation gap'. The underlying belief in this analysis is that Europe would not put enough capabilities at its disposal in order to efficiently pursue a European level foreign policy. Authors have blamed lack of finances, 'precedent and procedure', 'lack of leadership' (Peterson, 1998: 6) and perhaps more essentially 'contradiction between the ambitions of EU member governments to play a larger international role and their reluctance to move beyond an intergovernmental framework in doing so' (Hill \& Wallace, 1996: 5) (Bretherton \& Vogler, 2006). Jensen et al. (2007) attribute the paradox to national party preferences rather than national government preferences. 
Scharpf (2006) uses the words 'joint-decision trap' to describe the desire of Member States to retain influence over supranational matters.

\subsection{EEAS infancy}

Academic literature on the birth of the EEAS is seriously lacking. This is quite understandable when considering that Commission approved its creation on the 20 July 2010, followed by a Council decision on the 26 July 2010. Financial regulations and staff status were only approved by the European Parliament on the 20 October 2010. In this section I will therefore review some of the opinions that have circulated since the service's genesis.

Much of the articles published refer to the EEAS in a very descriptive way. Plainly, authors are concerned about the shape the bureaucracy is going to take. Several question the 'double hat' of the service (Grässle, 2011). Descriptions abound about the nature of the merger between Council staff and Commission staff, with the added input from national diplomatic services (Hillion \& Lefebvre, 2010; Carta, 2011; Brok, 2011). The 'capabilitiesexpectation gap' (Hill, 1993) of the 90s, is not forgotten. Carta (2011) describes this new instrument of foreign affairs as 'only a quasi-diplomatic service, which represents 'instances' of foreign policy and relies on coordination among all European actors'. Hillion \& Lefebvre (2010: 7) share more idealism when stating in a true neo-functional spirit that the EEAS 'is possibly the starting point of a more integrated European diplomacy'.

Despite the relative infancy of the service, Gross \& Rotta (2011) describe what seems to be an initial success. In September 2010, the HR/VP with the backing of Member States persuaded Serbia to sponsor a joint resolution in the United Nations General Assembly (UNGA) calling for a Pristina - Belgrade dialogue. 
What the authors portray as a success is mitigated by division within the Council on issues such as the recognition of Kosovo, with only 22 Member States having done so officially. Not much seems to have changed. In their analysis, Gross \& Rotta also amalgamate the EEAS with the position of Catherine Ashton. One should be careful to differentiate the two, especially considering that in September 2010, finances and staffing of the service had not yet been approved by the European Parliament.

Gross \& Rotta however do touch upon an interesting point. Because the EEAS is intended to be the sword wield by the HR/VP, its success can only be judged by the effectiveness of its wielder. This signifies that the EEAS is bound to play a secondary role as an instrument to the HR/VP. As the latter takes centre stage in foreign policy coordination and policy making, the political entrepreneurship literature needs to be considered in order to gauge the potential of the EEAS. In this regard, constructivists such as Barnett \& Finnemore (1998) argue that bureaucratic politics empower entrepreneurs to shape international affairs. Sandholtz \& Zysman (1989) further argue that supranational entrepreneurship is the only explanation to treaty amendment in the European Community. While Moravcsik (1999) is quite skeptical about the role of supranational institutions in inter-State bargaining, he does propose a 'two-level' bargaining theory which identifies space for supranational entrepreneurs to act. As he suggests however, one may easily fall prone to a lack of scientific rigor when discussing entrepreneurship. As a result, this paper will address the issue of EEAS - HR/VP effectiveness within a game theoretical framework. 


\subsection{Applying game theory}

Given the complex nature of politics, it is not surprising that game theorists have found a variety of representations to explain its mechanics. The purpose of symbolising legal and political procedures through games could be explained as one of two reasons: either to see toward which actors the game is biased, or to provide strategic recommendations.

In 1988, Robert Putnam pioneered the two level game literature which changed the way scholars conceptualized international bargaining. He contended that in order to understand the dynamics of inter-States bargaining, one had to analyse preferences across two levels: domestic and international. Only when the winsets of both interacted was it possible to successfully find a new equilibrium (Putnam, 1988). This article expended on Schelling's thought that 'the power of a negotiator often rests on a manifest inability to make concessions and to meet demands' (1960: 19), by asserting that a small winset on a given level would strengthen one's position across the second level. This thinking led Tsebelis (1990) to question perceptions of rationality. Actions by players which may appear irrational are often due to the illusion that a game is played in isolation. In order to perceive real winsets, one must distinguish nested games.

The European Union has since been at the centre of a vast literature exposing its legal and political procedures through game theoretical representation. Garett and Weingast (1993) used the Battle of the Sexes scenario embedded within a standard Prisoners' Dilemma to best capture the cooperation dilemma under an EU institutional framework. While the analysis is quite simplified, it conceptualizes very well the rationale behind Member States' willingness to bind themselves under institutional rules. Bringing cooperation 
to an extreme, Jacobs et al. (1995) contend that the Council often acts as a unified body, therefore implying shared preferences.

In order to take into account the intricacies of players' preferences and procedural frameworks, the literature evolved into spatial representation (Tsebelis, 1997; Garrett \& Tsebelis, 1999; Tsebelis \& Garrett, 2000; Hosli, 2000; Meunier, 2000; Tsebelis, 2002). One-dimension and two-dimensions spatial models have allowed the verification of certain assumptions, such as the importance of agenda setting. Garrett and Tsebelis (1999) reason that the Commission, as the agenda-setter, has the opportunity to present strategic proposals to the Council. Also, the power of the agenda setter increase with the number of dimensions (Tsebelis, 1997). As Member States allocate different weights to the issues being negotiated, package deals and side payments are a possible way to increase all players' utility (Scharpf, 1997). An innovative Commission with perfect information should therefore find itself with a lot of influence over the negotiation.

Hosli (2000) rationalizes that EMU negotiations are best understood through two-dimensions spatial models accounting for domestic preferences in a traditional two level game approach. This allows for an equilibrium to appear which is acceptable to all parties. In a unanimity voting context, players with winsets outside the chosen equilibrium are allowed to opt-out. Garrett and Tsebelis (1996: 281) maintain that unanimity voting results in a conservative position, which when reached is the 'lowest common denominator'. Failing that, the status quo remains.

Spatial representation models are not without critics however. Junge and König (2007: 466) demonstrate through regression analysis simulations that the 'dimensionality of the policy space and the inclusion of actors' saliencies are much more important for empirical analysis than the identification of the 
agenda setter or the weighting of votes'. While such a critic questions prediction on policy outcomes, several fundamental mechanisms are still valid.

Building on this literature, this paper intends to illustrate the importance of agenda setting and the hidden redistributive impact of preference formation in the context of unanimity decision making. The analysis used will derive optimal strategies to be followed by State actors under the described models.

\section{Decision making and the importance of agenda setting in the Foreign Affairs Council}

Henry Kissinger is widely respected both as a political realist and as a US statesman. These words he uttered, 'Europe, who do I call if I want to call Europe?', in describing the lack of EU coordination have haunted Europeans for decades. At the heart of the taunt is a reminder that the EU is 'neither a state nor an international organization' (Sbragia, 1992: 257). As the EU moves towards greater integration, an ever closer union in the words of Robert Schumann, there is a growing desire from Member States to cooperate more heavily on foreign policy. This is acknowledged in the Treaty on European Union established in Lisbon. With the introduction of the position of High Representative of the Union for Foreign Affairs and Security Policy, voices have been heard claiming that finally Europe had a number. Optimism did not run too high in Brussels where the realities of bureaucratic institutionalism are well known. The Economist ran a piece in September 2010 noting the following: 
A joke doing the rounds in Brussels has Cathy Ashton, the European Union's foreign-policy chief, telling Hillary Clinton she now has the single telephone number so that America can "call Europe". But when the secretary of state dials it, all she gets is a recording: "For French foreign policy, press 1. For British foreign policy, press 2 ...” 1

This section of the paper will focus on cooperation and decision making in foreign affairs. I will introduce a two-dimensions spatial model that will outline the mechanics of decision making by unanimity votes in the Council. Through this model, we will evaluate the role of the HR/VP, and his (her) potential influence on policy outcome. We will argue the importance of agenda setting when combined with the ability to lead discussions and mediate. This analysis will show that small ${ }^{2}$ Member States may benefit from keeping transaction costs low, and using the EEAS as a focal point for information sharing. By doing so, through the EEAS, the office of the HR/VP finds itself empowered in the negotiation.

\subsection{Methodology}

As with all games, it is necessary to define the terms and explain the methodology used in the model. As is standard in international relations, we will have a set of players. These could be States, institutions or even individuals. As we will be analysing decision-making within the Council of Foreign Affairs, the players in this particular case will be the Member States of the European Union and the HR/VP, as a supranational entrepreneur with the backing of the EEAS.

\footnotetext{
${ }^{1}$ The Economist, 16th Sep 2010.

2 The paper's use of words 'small' and 'large' MS in the context of negotiations refers not to the physical or demographic size of countries, but rather their weight and influence in diplomacy.
} 
This paper bases itself on Article 31 TEU to assert that the rules of the game will be based on unanimity voting, where all State players have a veto power ${ }^{3}$. According to the treaty, qualified majority decisions, apart from the nomination of special representatives, follow unanimity decisions by the European Council. In effect, ministers of foreign affairs may only adopt decisions by qualified majority voting (QMV) once the heads of States and governments have unanimously decided to let them do so. By representing the State as a unitary actor, this game alleviates this confusion and ignores QMV entirely.

The game is based on policy outcomes. The starting point is called the status quo. If an agreement is reached between all State players, the policy shifts to a new agreed position - called new equilibrium. If no agreement is reached, the status quo remains, a case best described as policy stability. Policies are defined by two dimensions $\mathrm{x}$ and $\mathrm{y}$. Having two items to agree on reflects non-linear policies. As noted by Junge and König (2007), the number of dimensions clearly has an important impact on the game. The choice of twodimensions spatial representation is due to a desire for simplicity and legibility.

Every player has different preferences across the two selected dimensions $x$ and $\mathrm{y}$. In a two-dimensions spatial model, this is represented by a circleshaped indifference curve centred around a point indicating the player's optimal preference. The size of the circle is endogenous to the distance of the optimal preference point from the status quo. Players will favour any point on the two-dimensions model located closer to their optimal preference point than to the status quo. Junge and König (2007) also emphasize the importance

\footnotetext{
3 The HR/VP does not have any veto power. He (she) does however have the position of president of the Council which allows him (her) to drive discussions and mediate between State players.
} 
of saliencies. It is indeed quite a rare occurrence when a minister is tasked to defend all negotiated items with the same zeal. Consequently, the indifference curves of State players are in reality rather oval-shaped than circle-shaped. The latter constitutes the exceptional case where no single dimension matters more than the other. The player is indifferent between $x$ and $y$.

In the two-dimensions spatial model, the area where the preferences of all State players intertwine is called the unanimity set. It is interesting to note that, when moving from the status quo to a new equilibrium, the latter must necessarily be located within the unanimity winset of players due to the voting procedure.

Junge and König contend that 'voting weights only shape outcome when qualified majority rule applies in Council' (2007: 475). Interestingly, Meunier (2000) reasons that veto powers are not all equal. According to her argument, a threat of veto by France would hold more weight within Council then a similar threat by Belgium, all things being equal. The following game will take Meunier's remark into account by acknowledging that weighting affects the chosen equilibrium point within the unanimity winset. We thereby acknowledge that each Member State's veto has equal mechanical effect, while leaving room for manoeuvre within the unanimity winset.

\subsection{Coalitions when 27 players matter}

Figure 1 below illustrates a scenario with four players (Austria, Belgium, Czech Republic and Denmark) ${ }^{4}$. Indifference curves, represented by the circle and oval shapes, intersect in the point SQ (status quo). SQ represents the prenegotiation position of the EU on a particular foreign affairs policy. The

${ }_{4}$ The countries in this example are selected on the basis their first letter to be listed alphabetically. 
objective of each player is to draw the policy outcome of the negotiation closer to their optimal preference located at the centre of the oval shapes. Because of the unanimity voting procedure, players will always veto an outcome that is outside of their indifference curve. Consequently, policy change is only possible when the new equilibrium point is located within the unanimity winset (grey area common to all indifference curves).

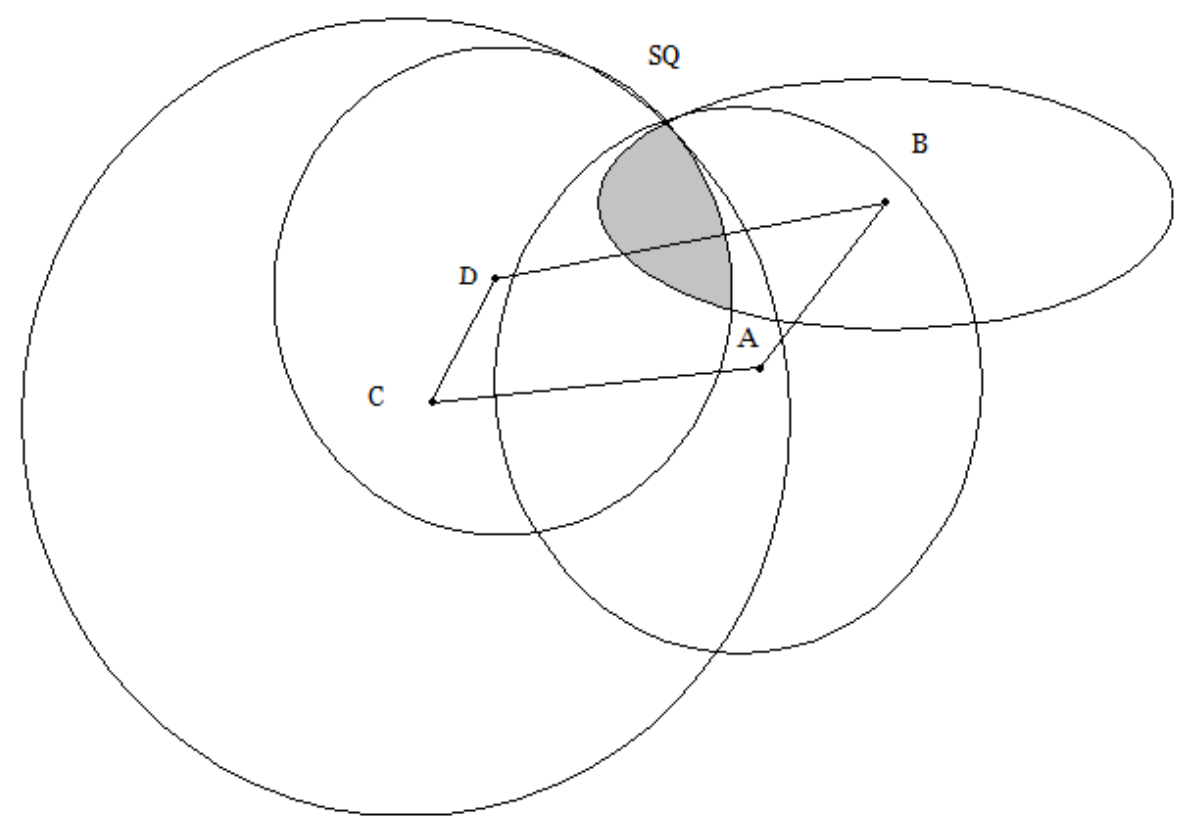

Figure 1 - Unanimity voting procedure with four players

We can see in the figure that the common winset between Austria and Belgium or Austria and Denmark is much larger than the unanimity set. We also notice that the latter is equal to the winset between Belgium and Denmark. Austria and Czech Republic's indifference curves do not affect the common winset. As Tsebelis (2002: 24) asserts, adding veto players either lowers the unanimity winset or lets it remained unchanged. In the latter case he concludes that their preferences therefore do not 'matter'. Our working assumptions however contradict his conclusions. Indeed Austria and Czech 
Republic will find any agreement between Belgium and Denmark agreeable. They nonetheless matter if we consider a game where discussion, and therefore persuasion and coercion, takes place. In such a case, weighting does matter. While this model cannot accurately predict the exact location of the equilibrium point, it can point out all participating players may have an impact on its position within the unanimity winset.

\subsection{The powers of the agenda setter}

In the assessment of his 'joint-decision trap' approach and as a reflection on his overall reasoning, Fritz Scharpf admits being 'embarrassed by having ignored the Commission's role as an agenda setter and its capacity for reducing the transaction costs of negotiated agreements' (2006: 851). Agenda setting is an important function in any negotiation. As with transaction costs, when the number of players increase, so do agenda setting powers (Tsebelis, 2002). Discussion becomes difficult between all players and information is costly. The agenda setter may lead the discussion and provide information at a relative low cost. This alone provides an agenda setter with substantive influence over the outcome of a negotiation. It is therefore surprising that the Commission has traditionally been reluctant to initiate proposals in the field of the CFSP. As noted by Cameron (2003: 3), 'to the regret of many' the Commission makes no use of this very important instrument.

In figure 2 we represent a negotiation between twenty seven Member States in Council under the unanimity voting procedure by grouping them into three coalitions E,F and G. We previously established that any new equilibrium could only be found within the unanimity winset (grey area). Any other proposal would be subject to veto. Each player therefore has an interest in advancing the agenda to the point within the unanimity winset 
which is closest to his optimal preference point. In this figure we have represented each coalition's preferred equilibrium as E', $F^{\prime}$ and $G^{\prime}$. Interestingly, each of these points are located within the E,F,G triangle, which represents the Pareto optimal winset. Within the Pareto optimal winset, an equilibrium point may not be moved without decreasing the utility of at least one other player. In a unanimity voting procedure, the proposal would be vetoed. If the status quo is located within this area, the outcome is policy stability. We can therefore infer from this model, that if the preferences of all other players are revealed, it is in the interest of the agenda setter to propose a policy that within the unanimity winset is closest to its optimal preference point. This policy proposal would fall under the Pareto optimal winset. As any modification to this proposal would be disadvantageous to at least one other player, each player would face the choice of either keeping the status quo or accepting the new proposal.

Under article 30.1 TEU, agenda setting powers do not fall under the exclusive hands of the Commission. Under the CFSP, each Member State and the HR/VP may initiate proposals. There are twenty eight potential agenda setters. In the past the Commission shied away from agenda setting, but with a functioning EEAS the HR/VP might find himself (herself) empowered. 


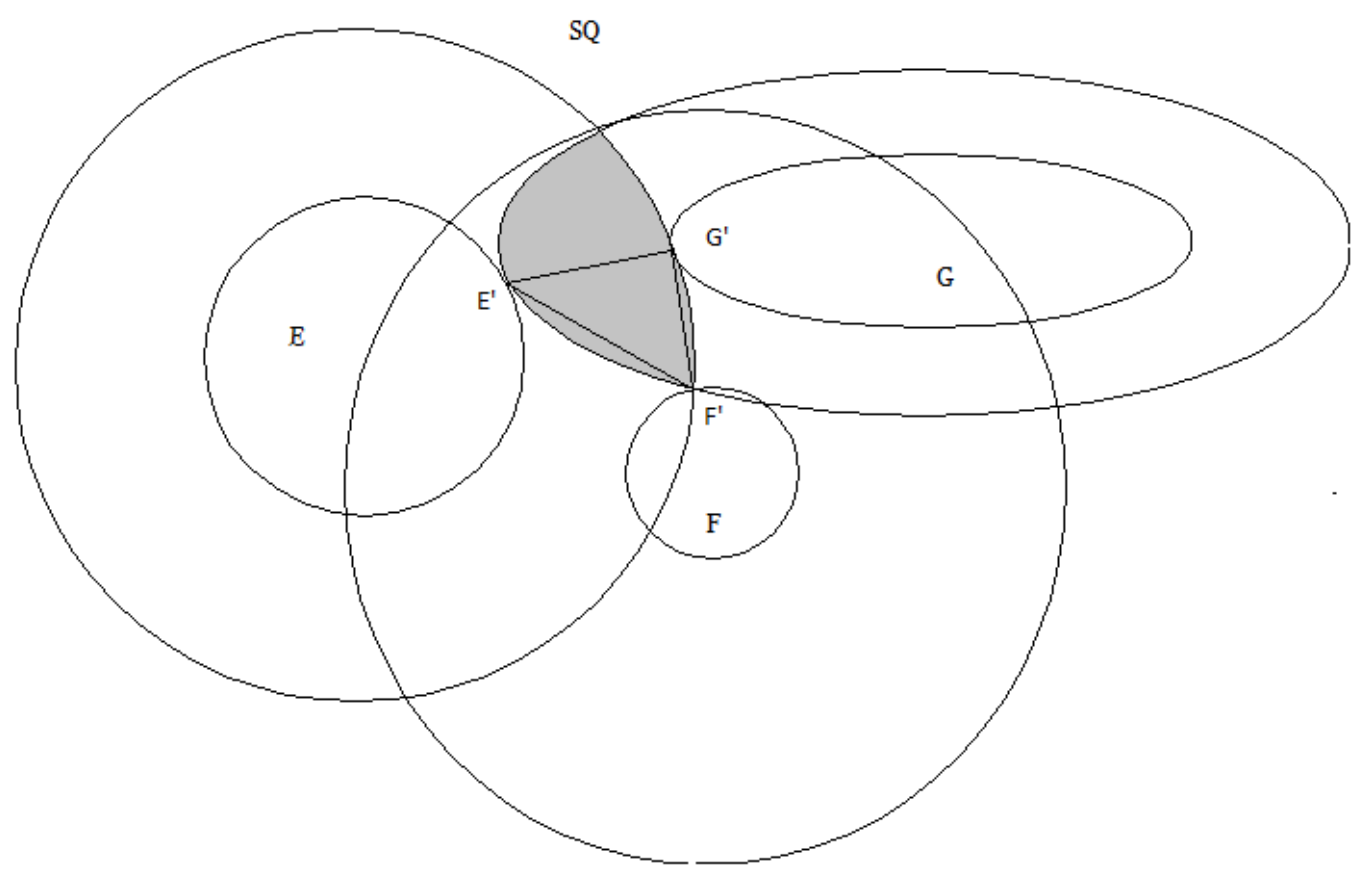

Figure 2 - The importance of agenda setting under unanimity voting procedure

\subsection{The Empowerment of the agenda setter}

As mentioned beforehand, transaction costs in a negotiation between twenty seven Member States are potentially quite high, although they can be mitigated by a chair / agenda-setter. Tsebelis (2002) asserts that these costs affect decision making. He does however conclude that players will only accept policy change if the change itself is significant. This paper reveals a time inconsistency issue which draws different conclusions. While costs of obtaining information, forming coalitions and bargaining over policy are incurred during the negotiation process, the benefits of the policy are only gained after it has been adopted by the Council. Keeping the status quo once the costs have been incurred by the players puts all in a worst off position. If utility can be improved, even at the margin, players will be tempted to accept the new policy. 
Game theoretic concepts allow us to advance one step further. We know that information is not complete in this game. It takes a considerable amount of investment to obtain relevant information on the positions of all players and to bargain efficiently. The policy result is uncertain. According to Tsebelis and Garrett (2000), complete information assumes that negotiation is not possible as the agenda setter would propose a solution acceptable by all. Nonetheless, the game makes the assumption that the EEAS benefits from a well informed staff composed of national seconded diplomats from all 27 Member States, in addition from supranational staff. The European service benefits from a network of information which is relatively less costly in comparison to Member States'. National governments however need to choose between a low investment strategy where they know if the policy proposed is more or less advantageous than the status quo, or a high investment strategy where information is nearly complete (as with the EEAS) in order to attempt to swing the negotiation in their favour. By inputting this situation in a Prisoners' Dilemma type matrix, we are able to infer the empowerment of the agenda setter.

Let us assume a game similar to Figure 2, where the preferences of all players are represented by three main coalitions. Coalition E is led by the HR/VP with the assistance of information gathered by the EEAS, and regroups a few countries that have low national interests at stake, or stakes that are in line with the community interest. Coalition F is led by France and coalition G by Germany. The EEAS has gathered much information on the position of all players and has a fairly accurate understanding of each coalition's indifference curves. The information has arrived on the desk of the HR/VP, who decides to act by submitting a policy proposal E' to the Foreign Affairs Council (figure 2). Being the first mover, the HR/VP is said to be the agenda setter, in addition to being the president of the Council. With an initial low 
transaction cost, both coalitions F and G are able to establish that the utility gains in moving from the status quo to $E^{\prime}$ are not negative. Proposals that have been made to move away from E' have raised opposition from several Member States. E' is Pareto optimal. F and G both have the possibility to invest highly in the negotiation or not, which would result in more information being revealed and side payments being given or received. Nevertheless, the Pareto efficient proposal seems to be impossible to beat given the unanimity voting procedure. Both coalitions have two sets of strategies. Firstly they may choose a low investment or a high investment into the negotiations. Secondly, they may accept or veto the policy proposal initiated by the HR/VP. The payoffs are different in each case. A low investment allows free-riding whereas benefits may be ripped with no transaction costs, while a veto can be applied if the status quo is preferred. If the policy is rejected, a low investment implies neither gains nor losses. A Member State may wish to implement a high investment strategy to bring the equilibrium point closer to its optimal preference. A high investment strategy however only yields results when a large number of players use a low investment strategy. A situation where all use a high investment strategy is self defeating. If the proposal is rejected under a high investment strategy, the coalition will be worst off that the initial status quo. The matrix below summarizes this, where $\mathrm{R}$ stands for reward (even marginal), 0 implies no change in utility, and L stands for losses (even marginal). 
Low investment for $\mathrm{G} \quad$ High investment for $\mathrm{G}$

\begin{tabular}{lcc}
\hline Low investment for $\mathbf{F}$ & $\mathrm{R}, \mathrm{R}$ & $\mathrm{R}, \mathrm{R}$ \\
\hline High investment for $\mathbf{F}$ & $\mathrm{R}, \mathrm{R}$ & 0,0 \\
\hline
\end{tabular}

Figure 3.1 - Prisoners' Dilemma where policy initiated by HR/VP is accepted ${ }^{5}$

Low investment to $G$ High investment to $G$

\begin{tabular}{lll}
\hline Low investment for $\mathbf{F}$ & 0,0 & $0, \mathrm{~L}$ \\
High investment for $\mathbf{F}$ & $\mathrm{L}, 0$ & $\mathrm{~L}, \mathrm{~L}$ \\
\hline
\end{tabular}

Figure 3.2 - Prisoners' Dilemma where policy initiated by HR/VP is refused

In a situation where the policy proposal is accepted, a strategy where neither coalition invests highly results in rewards for both and an empowerment of the agenda setter. If only one coalition invests highly, it may sway the equilibrium point closer to its optimal preference point (as long as it remains within the unanimity set). Here as we have seen, size and influence matter. The coalition which does not invest highly in this negotiation however still may veto any position which is worse than the status quo. In a situation where the policy proposal is refused, players simply loose what they have invested.

The two-by-two matrix (Figure 3) reveals a unique Nash Equilibrium in the case of the policy being refused. The dominant strategy is to free ride by minimizing transaction costs. The Nash Equilibrium is also Pareto optimal,

\footnotetext{
5 Payoffs illustrated in the 2-by-2 matrices in this paper must be read as: (Payoff for row player,
} Payoff for column player). 
which signifies that neither F nor G have any incentive to deviate. If the policy is accepted, all conditions except one where both players invest highly are Pareto optimal.

The game can also be structured as a decision tree (Figure 4), highlighting the sequence of policy proposal, the choice of each player's investment strategy and the final rejection or acceptance of the policy. By backward induction, an additional dominant strategy appears. Players must always accept the policy proposal6. While in the Council sequence has arguably low relevance, this model is interesting when combined with our above assumption that weight, coalition size and saliency matter. This would therefore lead us to conclude that the dominant strategy is dependent upon these variables. Member States need to gauge the importance of the issue being debated in Council and only invest highly in the negotiation if two requirements are met: (1) The issue is one of national interest, and probably not sufficiently served by the agenda setter (2) Through coalition building, the concerned party is able to sway other coalitions away from the Status quo. If neither condition is met, States' optimal strategy would be to free ride.

\footnotetext{
${ }^{6}$ They must always accept under the defined conditions: the agenda setter proposed a policy which was at least as good as the status quo (situated on the same indifference curve or deeper within the unanimity winset).
} 


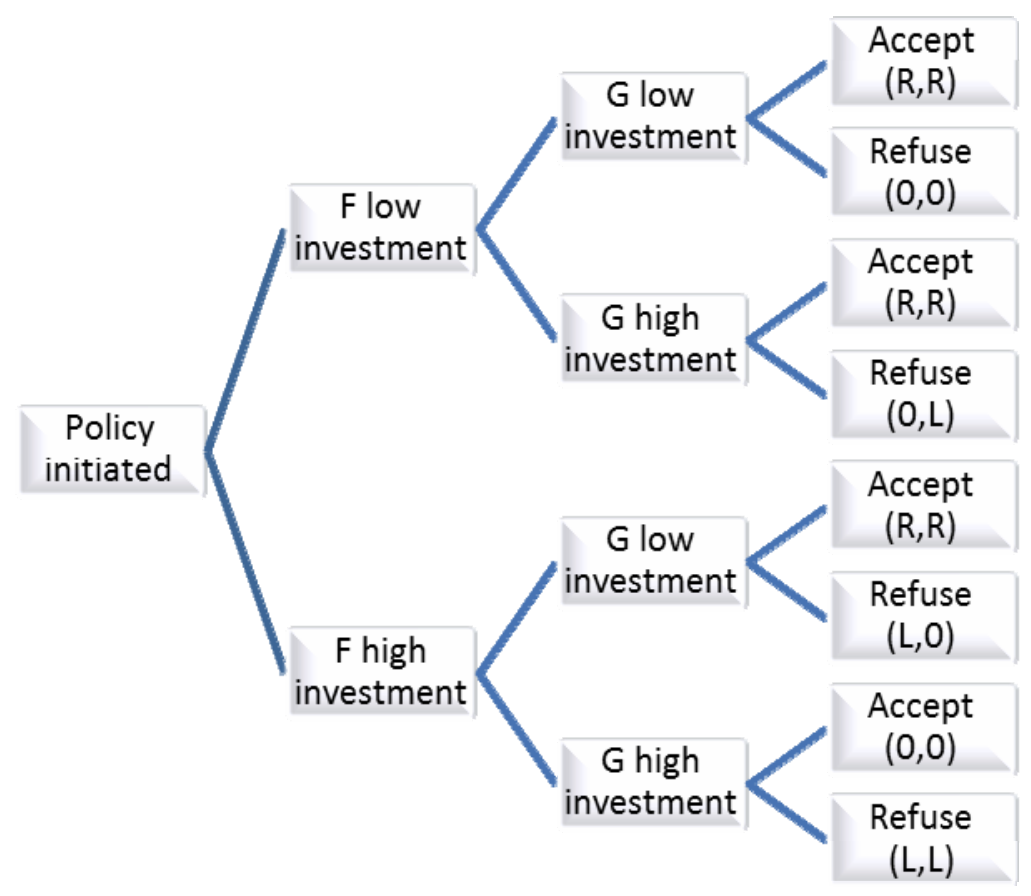

Figure 4 - Decision tree representing investment choices and policy outcome

Interestingly, the power of the agenda setter is greater when other players have low investments in a negotiation. They are more willing to accept a policy proposal when free riding, due to low transaction costs. In our example, the HR/VP finds himself (herself) empowered not only by initiating a proposal and driving the discussions, but also by the superior information provided by the EEAS. By having delegates of all twenty seven Member States within the bureaucracy, the EEAS has the ability to provide key advice at low costs. In its absence, each Member State would need to conduct 26 bilateral negotiations to inform themselves adequately. This allows us to establish that the EEAS has the ability to bring transaction costs down and empower the HR/VP as an ideal agenda setter within the Foreign Affairs Council.

Scharpf (1997: 145) noted that transaction cost could be reduced with the presence of an 'external agenda setter to assess the limits of acceptability for 
all participants and to propose a jointly acceptable solution - if one exist'. He goes on to say:

Such services are typically performed by the central staffs of associations or by the "secretariats" of international organisations. Precisely because they can neither offer favors of their own nor inflict punishment, they are likely to be accepted as an "honest broker" whose good offices may enable governments that are much more powerful than themselves to reach outcomes that they could not have reached on their own. (Scharpf, 1997: 145)

In this section we have represented a two-dimensions spatial model of decision making within the Foreign Affairs Council under unanimity voting procedure. We have reasoned that weight, saliencies and coalition size matter in shaping policy outcome. By representing constellations of players within coalitions, we simplified the model to represent the preferences of all twenty seven Member States. We then introduced the notion of agenda setting as an important parameter of negotiation. With near complete information at hand, the agenda setter is able to draw the policy outcome to its preferred position under Pareto optimal conditions. Modelling the situation within a Prisoners' Dilemma matrix and a decision tree allowed us to explain that the dominant strategy for States is based on their relative power in Council and the salience of the issue. Also proposals must be accepted as long as they are at least as good as the status quo. This results in an empowerment of the HR/VP who finds himself (herself) supported by a well-informed 'honest broker': the EEAS. 


\section{EEAS: An Intergovernmental European Ministry of Foreign Affairs}

The previous section argued the potential empowering of the office of the HR/VP on the assumption of near complete information from its service: the EEAS. The introduction of the service within the institutional make-up changes the game of EU diplomacy. The European External Action Service is a merger of different existing European Commission's Directorate Generals (DGs), including staff from the General Secretariat of the Council, as well as a host to national diplomats serving on a temporary basis. The role of the EEAS is defined in Article 27 of the Treaty on European Union as providing assistance to the High Representative in fulfilling his mandate and cooperating with national diplomatic services. Because of the nature and intent of this institution, a paper analysing how the Lisbon Treaty will affect EU foreign policy needs to focus on several key aspects.

In the first part of this section, we will analyse the EEAS to reason that its organisation, costs and supranational roots make it an efficient coordination instrument. Secondly, we will discuss its impact on EU Member States representations to third countries in order to show a cost alleviation mechanism which results in an empowerment of the service and redistribution effects across the Union. We will then end on the consideration that the CFSP remains quintessentially inter-governmental.

\subsection{Efficient coordination}

This paper attempts to shed light on how the introduction of the EEAS within the EU institutional setting serves as a game changer for EU diplomacy. 
Surely an important aspect to consider is the reasoning behind its creation. What is the rationale behind the institutional change? While the CFSP was institutionalized formally in Maastricht, the European diplomatic service serves as a coordination reinforcement mechanism. Rational choice institutionalism makes a compelling case in justifying institutional change. States create institutions because they are either more efficient then the status quo, or because they allow redistribution. In either case, they are expected to 'generate a stream of income over time, that is, they constitute assets that can be used whenever needed in the political arena' (Tsebelis, 1990: 100). Because of the unanimity dynamics embedded both within treaty amendments and CFSP voting procedure, we initially explore efficiency as the most viable answer. Gains can be achieved through a more efficient coordination.

With an initial budget of $€ 475.8$ million for 2011, the EEAS is not without impact on the EU budget. This figure is expected to grow to $€ 3$ billion as the service expands7. According to German MEP Elmar Brok however, 'in comparison with the national foreign services and in view of its efficacy and the reduction in duplicate administrations that it will lead to no one can seriously maintain that this spending is out of all proportion' (Brok, 2011: 1). As the amount of positions created is rather limited, the EEAS does not add any significant costs to the EU budget. The new service will in effect be more efficiently integrated and help reduce transaction costs within EU institutions and Member States' administrations.

The underlying benefit of a coordinating institution from a negotiation point of view is rooted in its cost saving capacity. Indeed, economists would assert that economies of scale can be achieved through information gathering and sharing, and through the production of expert knowledge. This economic argument joins Haas' theory of neofunctionalism which promotes a

${ }^{7}$ BBC, 7th December 2010: http://www.bbc.co.uk/news/world-europe-11941411 
centralized institutional technocracy (Haas, 1964). In their constructivist account, Finnemore and Sikkink (1998: 899-900) contend that international organisations are staffed with experts who 'use expertise and information to change the behavior of other actors'. Up to $30 \%$ of its staff are expected to be national seconded diplomats. 'About one hundred posts are to be created within the Service in 2010 (including 80 in delegations) and 350 will be added by 2013' (Hillion \& Lefebvre, 2010: 5). Consequently, the EEAS will benefit from having a dual background staff; with one foot in the supranational environment, the other foot in national services. They would not only have adequate diplomatic training, similar to EU Member States, but also be exposed to the supranational spirit of EU institutions. The EEAS will therefore be in a prime position to invent 'institutional options' (Young, 1989: 355), which would not appear as clearly to national diplomats.

Although the bureaucrats transferred from the DGs and the Secretariat of the Council will arguably already be relatively supranationally inclined, the same cannot be assumed for national seconded diplomats. In this regard, both the Commission and the Parliament have expressed that it is important Member States be transparent in their affectations and that the EEAS be seen as a positive posting in view of re-integrating the national administration. Also, longer postings mean diplomats have a higher propensity to transition from a national inclination to a supranational one. As a result, the Commission has pushed in this direction. The agreement is for time of service, including mobility between Brussels and the delegations, to be 'limited to 8 years in principle - 10 exceptionally - for national diplomats' (Hillion \& Lefebvre, 2010: 6).

Although this paper is written at the genesis of the EEAS, the organisation of the service, its budget and its objectives seem to indicate a rather efficient reorganisation of EU diplomacy. The service will benefit from the small size 
of its bureaucracy allowing for fast response. Its size will also allow an efficient use of the information gathered through its extensive networks (Moravcsik, 1999). We can expect more information to be circulated and a European culture to be passed on to national seconded diplomats. It will also have an additional effect on several Member States: cost alleviation in diplomacy with third countries.

\subsection{Utility redistribution}

Change will also affect diplomatic representations in third countries. The birth of the EEAS and the reshuffling of the DGs under its umbrella alter the dynamics of EU diplomacy with its partners. Before Lisbon, heads of delegations abroad did not speak with the aggregated voice of the Union. They did however speak on behalf of the Commission where the treaties allowed, and represented the Union when mandated to do so. Under the new institutional arrangement, it is expected that these delegations serve as a greater focal point, especially when policy is agreed on in the Foreign Affairs Council. In such a case, the HR/VP is considered mandated by the Council. The EEAS and the delegations will in turn find themselves empowered.

The added power and mandate of the EEAS combined with the tendency of governments to reduce their budgets ${ }^{8}$ have a direct impact on national resources allocation. It can be rationally expected that representations of Member States will shrink in size, at least where stakes are low. The added benefit of the EEAS as a coordination instrument with the ability to serve the interest of the Union and speak for all will turn diplomatic representations into inefficient duplicates, at least in third countries where diplomatic activity

\footnotetext{
${ }^{8}$ The trend of decreasing budgets is considered exogenous to foreign affairs concerns, but linked to the high debt ratios of Member States at the time of writing and the global push for fiscal responsibility.
} 
was slow. For Member States with high stakes in third countries, the EEAS would serve as a justification for difficult budgetary cuts. Overall, the tendency will be to downsize. This in turn will benefit the European service, as Member States will increasingly depend on its network.

A Battle of the Sexes variant of the Prisoners' Dilemma provides a representative scenario to illustrate the mechanics behind policy formation. Let us assume a position with two main players Hungary and Italy. The policy at stake concerns a third country in which Italy has key interests and is heavily involved diplomatically. In opposition, Hungary is only served by a small mission and indeed obtains most of its support and information through the EEAS and EU delegation. Hungary desires policy P1, while policy $\mathrm{P} 2$ is preferable to Italy. We allocate payoffs ranging from 0 to 2, where 0 indicates no change in utility for the given Member State, 1 indicates minor positive change and 2 indicates the preferred policy outcome. The relationship is however asymmetric. Whereas Hungary is dependent on an intergovernmental agreement between Member States to have an impact in the third country, Italy may decide to use its own diplomatic resources. While Italy's preferred payoffs are dependent on Hungarian cooperation, its alternative to achieve the policy outcome unitarily tips the scale in its favor, as is illustrated in Figure 5.

\begin{tabular}{|ccc|}
\hline & Italy chooses P1 & Italy chooses P2 \\
Hungary chooses P1 & 2,1 & 0,1 \\
Hungary chooses P2 & 0,1 & 1,2 \\
\hline
\end{tabular}

Figure 5 - Battle of the Sexes under unilateral dependence in third countries 
In the above model, rationality dictates Italy's dominant strategy in choosing P2 would result in Hungary being left with little choice but to follow. A further dimension branching off from this model is that Hungary may ask for side payments in what would equate to a redistribution of payoffs (Scharpf, 1997: 140). This leads us to reason that in a first instance, influential Member States may benefit from the erosion of diplomatic services in other Member States, as they find their influence augmented. In a second instance however, less influential Member States, or those that are less interested in third country policies, may free ride and in addition bargain for side payment in exchange for their support. Both strategies can produce benefits, however existing influence and bargaining power are variables that ultimately determine output. By backward induction, only States that are relatively powerful in the international arena or in their relations with specific third parties will find it favourable to continue their heavy investment in foreign policy. Others may draw on their veto capacity to extract rent. In this section, we initially treated efficiency as the main rationale for institutional change, as opposed to redistribution (Tsebelis, 1990). Nonetheless this paper argues that while introducing the EEAS brings efficiency gains, side payments and package deals allow for an alteration of payoffs, ultimately resulting in redistribution.

\subsection{The CFSP Hydra}

The above mechanism quintessentially transforms unanimity into consensus, while EU governments avoid decisions that would violate other Member States vital interests (Hayes-Renshaw et al, 2006).

One may draw from the two-level game literature in order to question the effects of the institutional change. In positioning the EEAS and CFSP in this 
framework, we establish that there are two bargaining levels: one across Member States and one in the international arena. Here there are many similarities with mandate diplomacy whereby the EU Commission is tasked by the Council to negotiate trade agreements with third parties. The HR/VP takes the role of the chief negotiator (Putnam, 1988), and is constrained on one side by the unanimity winset of the Council, and by the winset of third parties on the other side. We assume a constant winset on behalf of third parties, due to preferences being exogenous to the institutional set up of the EU. Mandate diplomacy under an unanimity procedures however results in agreement over the 'lowest common denominator' (Garrett and Tsebelis, 1996: 281). According to Schelling (1960) and Putnam (1988), this results in a stronger bargaining position for the Union in the international arena, as the EU is perceived as a tougher negotiator which is ultimately constrained by an unwavering Council. Unfortunately, this two-level game analysis ignores the alternative by which Member States may conduct diplomacy as usual if no agreement is reached in Council. This is the way in which EU foreign policy departs from EU trade as a form of mandate. By refusing to let go of their competence in foreign policy, Member States retain a business-as-usual alternative which defeats their prospective gains from mandate diplomacy.

Despite how the EEAS benefits EU diplomatic coordination, the game remains intergovernmental. Inter-State coordination does not equate to a merging of foreign policy. Member States retain their vetoes and will use them to protect their vital interests. The united voice of the EU can only be heard by mandated agreement. As a result, and due to the nature of foreign policy, the EEAS will be paralyzed by its decisional model. As the hydra of Greek mythology, the CFSP has many heads and all are of different minds. In times of crisis, such as the during the Arab Revolution of early 2011, swift central decision making at national government level make Member States 
better equipped to cope and respond in a timely manner. In such a circumstance, the EEAS shall sustain itself as a network of foreign policy rather than the arm of the European Union in world affairs. As long as Member States retain their sovereignty in matters of foreign policy, they will not adequately speak with one voice: no pain, no gain.

\section{Conclusions}

The paper builds on existing EU spatial representation literature by focusing on a relatively new development: the introduction of the EEAS and the office of the HR/VP. It acknowledges the criticism levied against past uses of the methodology, but argues valuable insights may nonetheless be drawn from it. Notably, coalitions' influence in negotiations may be acknowledged by including an unknown variable which will affect the location of the end-deal within the common winset. Saliencies can be addressed by altering indifference curves; in two-dimensional modelling this is done by representing indifference curves as ovals instead of circles. Also, in contradiction of Tsebelis's assumptions (2002), policy change need not be significant for players to accept it. There exists a time inconsistency whereby players incur bargaining costs which may only be potentially recovered through bargaining agreement. As a result, status quo may move, even if only at the margin. Despite the analytical limits of the model, agenda setting is highlighted as a powerful function, one which may benefit the HR/VP as chair of the Foreign Affairs Council given its access to a new supranational bureaucracy.

EU literature is accustomed to defining institutional change as either prointegration or an assertion of States' powers. This paper acknowledges the 
important role of governments in treaty changes and explains the rationale as being one of efficiency with hidden redistributive effects. The argument is that there are aggregate, and indeed Pareto optimal, benefits to the new structure. As a result both the EU, as a supranational actor, and Member States can be considered winners.

In the future it would be interesting to verify the assumptions made by this model with empirical evidence. This holds particularly true for the model's prediction of bargaining patterns between influential and less influential Member States, as well as future developments in third countries where the coordination/business-as-usual dilemma might bring added tension.

Perhaps scholars are right to declare the EEAS is 'the starting point of a more integrated European diplomacy' (Hillion \& Lefebvre, 2010: 7). Under the current institutional structure however, States remain at the center of foreign policy formation. The EEAS is merely a coordination instrument and must not be mistaken for anything more. 


\section{References}

Barnett, M. \& Finnemore M. (1999), 'The politics, power, and pathologies of international organizations', International Organization 53, pp.699-732.

Bretherton, C. \& Vogler, J. (2006), The European Union as a Global Actor (2nd ed.), London: Routledge.

Brok, E. (2011), 'Prejudices, Challenges and Potential: An Impartial Analysis of the European External Service', in Fondation Robert Schuman, European Issue n¹99, 21st March 2011.

Cameron, F. (2003), 'The future of the CFSP', Brown Journal of World Affairs, IX, 2, pp.1-10.

Carta, C. (2011), 'The EEAS: One for All, or One Among Many?', International Relations and Security Network, 25 March 2011 (available at: www.isn.ethz.ch, last accessed on 29/07/2011).

Finnemore, M. \& Sikkink, K. (1998), 'International Norm Dynamics and Political Change', International Organization 52 (4), 887-917.

Forster, A. \& Wallace, W. (1996), 'Common Foreign and Security Policy: A New Policy or Just a New Name?', in H. Wallace \& W. Wallace (eds) Policy-Making in the European Union, Oxford: Oxford University Press.

Garrett, G. \& Tsebelis, G. (1996) 'An Institutional Critique of Intergovernmentalism', International Organization 50 (2), pp.269-99.

Garrett, G. \& Tsebelis, G. (1999), 'Why Resist the Temptation of Power Indices in the EU', Journal of Theoretical Politics 11 (3), pp.291-308.

Garrett, G. \& Weingast, B. R. (1993), 'Ideas, Interests, and Institutions: Constructing the European Community's Internal Market', in Goldstein, J. and Keohane, R. O. (eds) Ideas and Foreign Policy. Beliefs, Institutions, and Political Change, Ithaca: Cornell University Press, pp. 173206.

Grant, C. (2009), 'How to make Europe's military work', Financial Times, 17 August.

Grässle, I. (2011), 'A Critical Analysis: the creation of the European External Action Service', in Fondation Robert Schuman, European Issue n¹94, 14th February 2011.

Gross, E. \& Rotta, A. (2011), 'The EEAS and the Western Balkans', in Istituto Affari Internazionali, IAI Working Papers 11 (15), June 2011.

Haas, E. (1958), The Uniting of Europe, Stanford, CA: Stanford University Press.

Haas, E. (1964), 'Technocracy, Pluralism, and the New Europe', in S. R. Graubard (ed.), A New Europe?, Boston: Houghton Mifflin, 62-88.

Hayes-Renshaw, F., van Aken, W. \& Wallace, H. (2006), 'When and Why the EU Council of Ministers Votes Explicitly', Journal of Common Market Studies 44, pp.161-194.

Hill, C. \& Wallace, W. (1996), 'Introduction: Actors and Actions', in C. Hill (ed.) The Actors in Europe's Foreign Policy, London: Routledge.

Hill, C. (1996), The Actors in Europe's Foreign Policy, London: Routledge. 
Hillion, C. \& Lefebvre, M. (2010), 'The European External Action Service: towards a common diplomacy?', in Fondation Robert Schuman, European Issue n¹84, 25th October 2010.

Hosli M. (2000), 'The creation of the European economic and monetary union (EMU): intergovernmental negotiations and two-level games', Journal of European Public Policy 7 (5), pp.744-766.

Huntington, S. (1993), 'The Clash of Civilizations', Foreign Affairs 72:4, pp.22-49.

Jacobs, F., Corbett, R. \& Schakelton, M. (1995), The European Parliament, 3rd ed., Essex: Longman.

Jensen, C. B., Saplin, J. \& König, T., (2007), 'Who calls for a Common EU Foreign Policy?: Partisan Constraints on FSP Reform', European Union Politics, Vol. 8 (3), p.387-410.

Kupchan, C. (2002), The End of the American Era: U.S. Foreign Policy and the Geopolitics of the Twenty-First Century, New York: Knopf.

Leonard, M. (2005), Why Europe will Run the 21st Century, London and New York: Fourth Estate.

Mearsheimer, J. (1990), 'Back to the future: Instability in Europe after the Cold War', International Security 15 (1), pp.5-56.

Meunier, S. (2000), 'What Single Voice? European Institutions and EU-US Trade Negotiations' International Organization, 54 (1) pp. 103-135.

Moravcsik A. (2009), 'Europe: The Quiet Superpower', French Politics Vol.7, No 3/4 (Sep-Dec 2009), pp. 403-422.

Moravcsik, A. (1997), 'Taking preferences seriously: A liberal theory of international politics', International Organization 51(4), pp.513-553.

Moravcsik, A. (1999), 'A New Statecraft? Supranational Entrepreneurs and International Cooperation', International Organization 53 (2), pp.267-306.

Moravcsik, A. (2008), 'Washington cries wolf', Newsweek, 31 March.

Peterson, J. (1998), 'Introduction', in J. Peterson \& H. Sjursen (eds), A common Foreign Policy for Europe? Competing visions of the CFSP, London and New York: Routledge.

Putnam, R. (1988), 'Diplomacy and domestic politics: the logic of two-level games,' International Organization 42 (3), pp.427-60.

Sandholtz \& Zysman (1989), '1992: Recasting the European Bargain', World Politics 42 (1), pp.95-128.

Sbragia, A. M. (1992), Euro-Politics, Washington, D.C.: Brookings Institution.

Scharpf F. (1997), Games Real Actors Play: Actor-Centered Institutionalism in Policy Research, Boulder, Oxford: Westview Press.

Scharpf, F.W. (2006): 'The joint-decision trap revisited', Journal of Common Market Studies, 44 (4), pp.845-864.

Schelling, T. C. (1960), The Strategy of Conflict, Cambridge, Mass.: Harvard University Press.

Schulz, H. \& König, T. (2000), 'Institutional Reform and Decision-Making Efficiency in the European Union', American Journal of Political Science 44 (4), pp.653-666. 
Smith, M.E. (1998), 'What's wrong with the CFSP? The politics of Institutional Reform', in P.-H. Laurent \& M. Maresceau (eds) The State of the European Union, Volume 4, Boulder, CO: Lynne Rienner.

Tsebelis, G. \& Garrett, G. (2000), 'Legislative Politics in the European Union', European Union Politics 1 (9), pp.9-36.

Tsebelis, G. (1990), Nested Games: Rational Choice in Comparative Politics, University of California Press.

Tsebelis, G. (1997), 'Maastricht and the Democratic Deficit', Aussenwirtschaft 52, pp.29-56.

Tsebelis, G. (2002), Veto Players: How Political Institutions Work, Princeton: Princeton University Press.

Walt, S.M. (1998), 'The ties that fray: Why Europe and America are drifting apart', The National Interest 54, pp.3-11.

Waltz, K. (2000), 'Structural realism after the cold war', International Security 25(1), pp.5-41.

Young, 0. (1989) 'The Politics of International Regime Formation: Managing Natural Resources and the Environment', International Organization 43 (3), pp.349-75. 
EU Diplomacy at 27: United in Diversity?

Eqs 


\section{Recent LEQS papers}

White, Jonathan. 'Parallel Lives: Social Comparison Across National Boundaries' LEQS Paper No. 47, January 2012

Meyer, Niclas. 'Political Contestation in the Shadow of Hierarchy' LEQS Paper No. 46, January 2012

Hyman, Richard. 'Trade Unions, Lisbon and Europe 2020: From Dream to Nightmare' LEQS Paper No. 45, December 2011

Wagner, Peter. 'The democratic crisis of capitalism: Reflections on political and economic modernity in Europe' LEQS Paper No. 44, December 2011

Chalmers, Damian \& Chaves, Mariana. 'The Reference Points of EU Judicial Politics' LEQS Paper No. 43, September 2011

Hassel, Anke. 'The paradox of liberalization - Understanding dualism and the recovery of the German political economy' LEQS Paper No. 42, September 2011

Hancké, Bob. 'Endogenous Coordination: Multinational Companies and the Production of Collective Goods in Central and Eastern Europe' LEQS Paper No. 41, August 2011

Crescenzi, Riccardo, De Filippis, Fabrizio \& Pierangeli, Fabio. 'In tandem for cohesion? Synergies and conflicts between regional and agricultural policies of the European Union' LEQS Paper No. 40, July 2011

Somek, Alexander. 'The Social Question in a Transnational Context' LEQS Paper No. 39, June 2011

Mabbett, Deborah. 'A Rights Revolution in Europe? Regulatory and judicial approaches to nondiscrimination in insurance' LEQS Paper No. 38, May 2011

Karaman, K. Kıvanç \& Pamuk, Şevket. 'Different Paths to the Modern State in Europe: The interaction between domestic political economy and interstate competition.' LEQS Paper No. 37, May 2011

Scharpf, Fritz W.. 'Monetary Union, Fiscal Crisis and the Preemption of Democracy.' Paper presented at the LEQS Annual Lecture 'Saving the Euro - at the expense of democracy in Europe?' on 12 May 2011 at the London School of Economics, LEQS Paper No. 36, May 2011

Zigante, Valentina. 'Assessing Welfare Effects of the European Choice Agenda: The case of health care in the United Kingdom.' LEQS Paper No. 35, May 2011

Hobolth, Mogens. 'European visa cooperation: interest politics and regional imagined communities.' LEQS Paper No. 34, May 2011

Monastiriotis, Vassilis. 'Regional Growth Dynamics in Central and Eastern Europe.' LEQS Paper No. 33, April 2011

Johnston, Alison. 'The Revenge of Baumol's Cost Disease?: Monetary Union and the Rise of Public Sector Wage Inflation.' LEQS Paper No. 32, March 2011

Glendinning, Simon. “Europe, for example.' LEQS Paper No. 31, March 2011

Winkler, Heinrich August. 'Greatness and Limits of the West. The History of an Unfinished Project.' LEQS Paper No. 30, February 2011 


\section{LEQS}

European Institute London School of Economics Houghton Street WC2A 2AE London

Email: euroinst.LEQS@lse.ac.uk

http://www2.lse.ac.uk/europeanInstitute/LEQS/Home.aspx

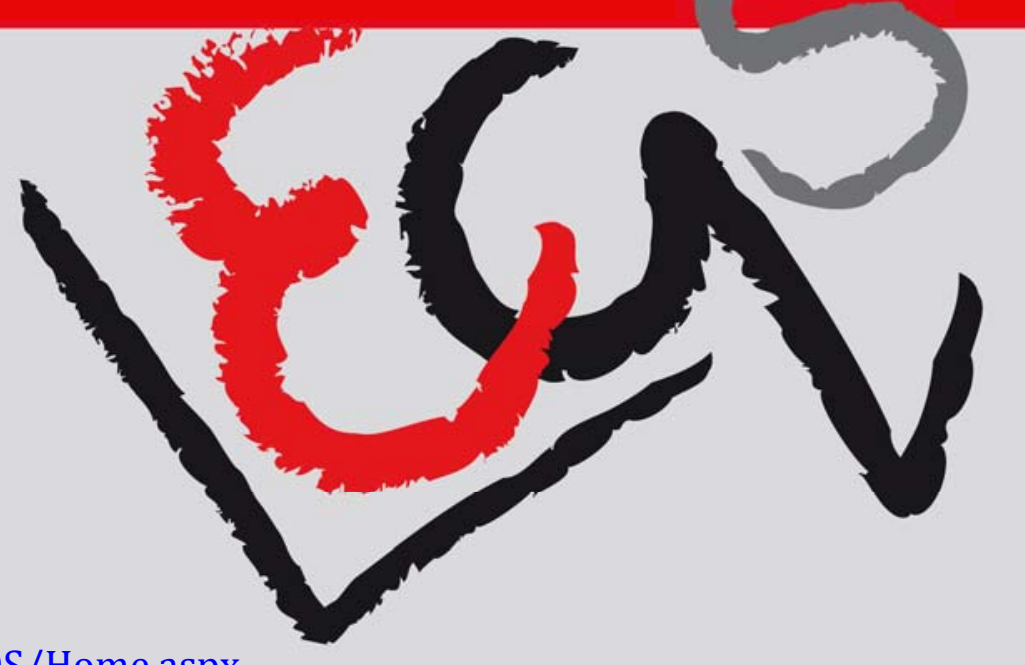

